IRA-International Journal of Education \& Multidisciplinary Studies

ISSN 2455-2526; Vol.10, Issue 03 (March, 2018)

Pg. no. 18-25.

Institute of Research Advances

http://research-advances.org/index.php/IJEMS

\title{
Tendency of English Teaching Based on Content-Based Instruction in China
}

\section{Yafang Li}

Postgraduate of Grade S161, School of Foreign Studies, Yangtze University, China.

Type of Review: Peer Reviewed.

DOI: http://dx.doi.org/10.21013/jems.v10.n3.p1

How to cite this paper:

Li, Y. (2018). Tendency of English Teaching Based on Content-Based Instruction in China. IRA International Journal of Education and Multidisciplinary Studies (ISSN 2455-2526), 10(3), 18-25.doi: http://dx.doi.org/10.21013/jems.v10.n3.p1

(C) Institute of Research Advances.

\section{(cc) BY-NO}

This work is licensed under a Creative Commons Attribution-Non Commercial 4.0 International License subject to proper citation to the publication source of the work.

Disclaimer: The scholarly papers as reviewed and published by the Institute of Research Advances (IRA) are the views and opinions of their respective authors and are not the views or opinions of the IRA. The IRA disclaims of any harm or loss caused due to the published content to any party.

Institute of Research Advances is an institutional publisher member of Publishers Inter Linking Association Inc. (PILA-CrossRef), USA. The institute is an institutional signatory to the Budapest Open Access Initiative, Hungary advocating the open access of scientific and scholarly knowledge. The Institute is a registered content provider under Open Access Initiative Protocol for Metadata Harvesting $(O A I-P M H)$.

The journal is indexed \& included in WorldCat Discovery Service (USA), CrossRef Metadata Search (USA), WorldCat (USA), OCLC (USA), Open J-Gate (India), EZB (Germany) Scilit (Switzerland), Airiti (China), Bielefeld Academic Search Engine (BASE) of Bielefeld University, Germany, PKP Index of Simon Fraser University, Canada. 


\begin{abstract}
The purpose of this study is to serve as guidance to academics that are starting or currently developing their research within the field of content-based instruction in China. This paper presents a bibliometric analysis on content-based instruction, making use of the National Knowledge Infrastructure database to perform it. The identified articles were analyzed concerning year of publication, citations, topics keywords and authors. This analysis comprises fundamental issues such as (i) the number of studies published per year, (ii) the most cited studies on content-based instruction between 2010 and 2018, (iii) the most frequent words used in the title of Content-based instruction studies in China, and (iv) assessment of studies citing content-based instruction. Results reveal a growth in the number of publications on content-based instruction for the 2010-2014 period. Although, since 2014 this growth has decelerated, the number of publications on this topic remains noteworthy. This study brings tendency of CBI in China for those academics and practitioners attempting to analyze and deepen within this particular field of research. At the same time it provides some insights concerning the future development and progress of content-based instruction in the English teaching.
\end{abstract}

Key words: Content-based teaching; Bibliometric analysis; CNKI

\title{
Introduction
}

In 1960s, content-based instruction (CBI) originated in Canada. The concept is to learn language through content, which is the core, regarding language as media. Students can get new information under the language environment the textbook offers. Since 1980s, the words content-based instruction has existed (e.g., May Shih, 1986). The basic theory of CBI comes from Input Hypothesis (StephenD, 1985). CBI teaching idea was explained and divided into 3 modes: sheltered model, adjunct model, theme-based model (Brinton, 2010). CBI was summarized 4 characteristics: (1) the subject content as the core; (2) the use of authentic language materials; (3) learning new information; (4) the curriculum must conform to different groups of students (Leaver \& Stryker, 1989). The "6T" method of CBI was put forward, such as themes, texts, topics, threads, tasks and transitions (Stroller, 1997).

In 1994, Wang Shixian published an article titled 'CBI - the direction of Specialized English Reading', introducing the concept of content-based teaching from abroad to scholars in China. English education in China has been basic English learning for a long time. Therefore the direct problem caused by this invariable basic English orientation is the exam-oriented teaching, slack learning, as well as time-consuming and inefficient system. CBI abandoned the meaningless and pure language training methods of traditional teaching, advocating that language teaching should be carried out while studying subject knowledge (Jigang, 2010; Pinghua, 2006\&2010; Runqing, 2011).

Cai $(2012,2010)$ conducted a questionnaire survey in China on College English learners who have learned basic English for many years, comparing the English level at the time of college and graduate, and almost half of them think that their English was not improved, even slightly decreased. He believed that it should be attributed to the basic English teaching. Some researchers stated basic English education at university has been unable to meet the needs of the students because of raising the level of English, which makes students lose their motivation and interest in learning English so that after graduation, it is difficult to immediately do professional English jobs(Zhenbang, 2003; Jigang, 2010\&2012). 
Many studies of CBI have been made before. Nevertheless, few papers gave the tendency and guidance of content-based instruction to academics in China. We aim to cover this gap, by analyzing further these complementary sources of bibliographic information. Hence, the main purpose of our study is to orient researchers and enable a wider understanding of the development of content-based instruction topic in China. This paper also might serve as an introductory reference and preliminary approach for new researchers targeting to become familiar with the literature on the development of CBI in China. To this aim, the article intends to clarify the concept of content-based instruction and subsequently develops a bibliometric analysis of the existing research on content-based instruction, trying to elucidate the direction and tendency of this topic during a period of 9 years (2010-2018) in China. The bibliometric analysis leads us to acknowledge which are the most frequent keywords and the most cited studies or what has been the number of studies on content-based instruction per year.

The paper proceeds as follows. The second section comprises a description of the research methodology. The third section presents the results of the bibliometric analysis. The fourth section brings the discussion. Finally, the fifth section presents the general conclusions and future work.

\section{Methodology}

This research was conducted using Bibliometric analysis. The research analysed included all articles registered with the subject of content-based instruction between 2010 and 2018 in National Knowledge Infrastructure (CNKI) the biggest official web of China. The following search strategy was used:

TOPIC: ("CBI*")

Refined by: DOCUMENT TYPES: (ARTICLE OR REVIEW ORPROCEEDINGS PAPER)

Timespan: 2010-2018.

Indexes: All Journals, SCI, EI, CSSCI, Core Journal.

The use of "[...]" in the above strategy means all kinds of derivatives of the CBI search term, by the above approach, 751 records were identified and studied. The search strategy was done on 13rd January 2018.

\section{Results and Findings}

\section{Quantification of Content-based instruction studies}

Based on the search strategy used in this study, the findings showed that 751 records were indexed in the field of content-based instruction in the National Knowledge Infrastructure (CNKI) database over a period of nine years (2010-2018). As shown in Fig. 1, the findings indicate that over the past nine years, there has been a zigzag growth of studies on content-based instruction, so that the number of researches rose from 33 in 2010 to 95 in 2018.

Table 1 and Fig. 1 present the number of publications per year on content-based instruction since 2010. During 2010 there were 33 published studies within CNKI. During the following 4 years, the annual volume of studies has been continually increasing. Since 2010 this expansion became more significant with an annual increase until the record of 127 studies published in 2014. The escalation in publications from 2010 can be explained by two factors: the increase of CBI researches, and the development of CBI from European countries to China. However, from 2014 to 2017, the number of publications has experienced a relative decrease, which may suggest that although the number of publications is still considerable, the topic might be entering a maturity phase in China. 
Table 1.Annual number of studies in content-based instruction.

\begin{tabular}{ccc}
\hline $\mathbf{R}$ & Year & Number of publications \\
\hline 1 & 2010 & 33 \\
2 & 2011 & 64 \\
3 & 2012 & 86 \\
4 & 2013 & 115 \\
5 & 2014 & 127 \\
6 & 2015 & 117 \\
7 & 2016 & 123 \\
8 & 2017 & 86 \\
9 & 2018 & 95 \\
\hline
\end{tabular}

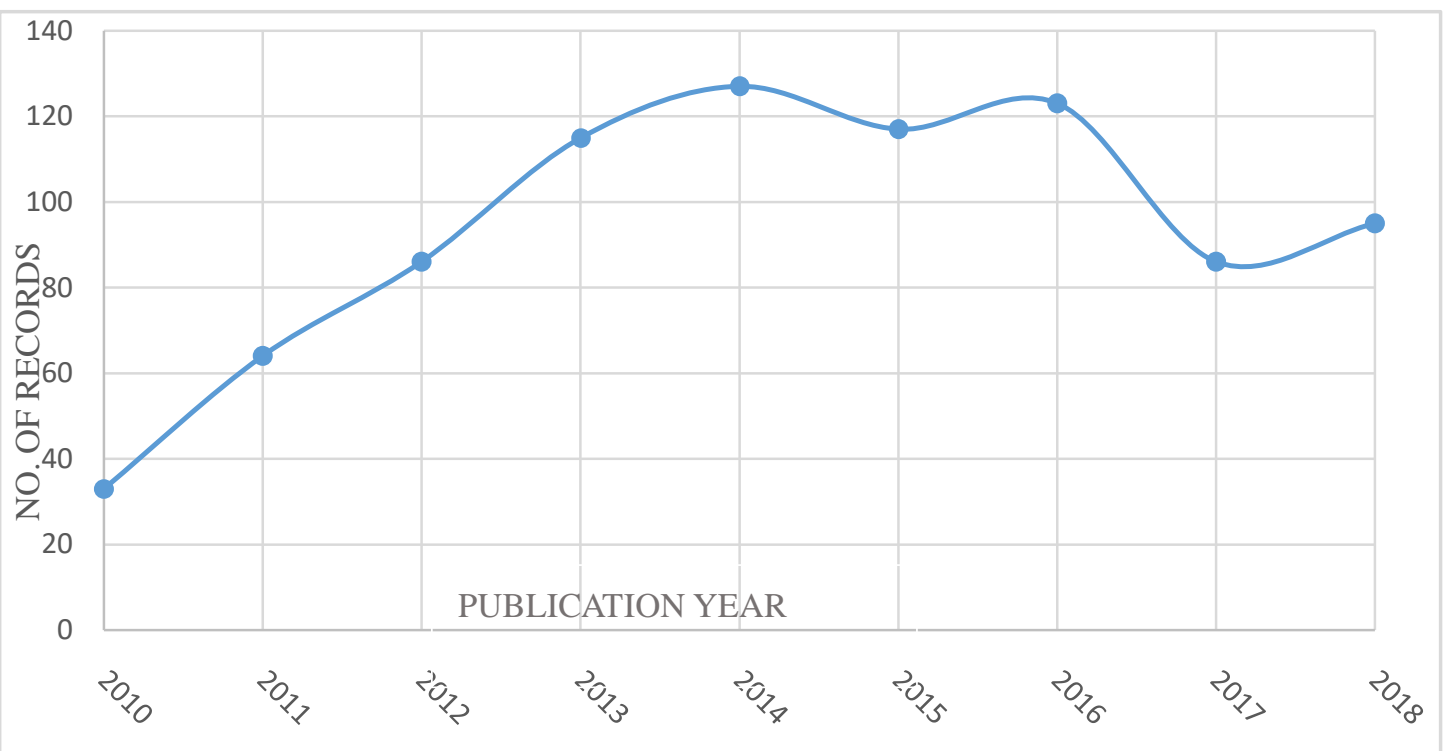

Fig. 1. Quantitative growth process of the studies concerning content-based instruction in the period of nine years.

\section{The 14 Most Cited Studies between 2010 and 2018}

To be able to know the tendency on the field of content-based instruction in China we carried out an analysis of the articles published in CNKI during the last nine years (2010-2018). To this aim,we have chosen the articles that have been cited at least 30 times. Table 2 shows the article's title; the name of the author, the date of publication and the type of study highlight the three most cited studies within this topic, which can be considered as seminal works that should be addressed by every research work in this field. These works are the following: in first place, "Discipline-based English Based On Content-based Instruction", from the authors CaiJigang. (2011), with 162 citations; Secondly, the study entitled "Direction Of College English Majors And English Teaching Reform Based On CBI And ESP In China” (Youzhong andLiwen,2011), with 135 citations. And, in third place, "Effect of CBI On English Majors'critical Thinking Skills" from Yang and Zhao. (2011), with 89 citations. On the other hand, table 2presents the studies with most citations in 2011.The three most cited studieshighlight different directions based on the approach of content-based instruction, such as discipline-based English, English teaching reform and the effect of CBI on English majors'critical thinking skills. Therefore we can see that most researches in China are still emphasized on the theory and direction of CBI. 
Table 2.The most cited studies on content-based instruction between 2010 and 2018.

\begin{tabular}{|c|c|c|c|}
\hline Rank & Author & Article & Type of study \\
\hline 1 & JigangCai (2011) & $\begin{array}{l}\text { Discipline-based English Based On } \\
\text { Content-based Instruction }\end{array}$ & Conceptual \\
\hline 2 & $\begin{array}{l}\text { YouzhongSun } \\
\text { LiwenLi (2011) }\end{array}$ & $\begin{array}{c}\text { Direction Of College English Majors And } \\
\text { English Teaching Reform Based On CBI And } \\
\text { ESP In China }\end{array}$ & Conceptual \\
\hline 3 & $\begin{array}{c}\text { DexiangYang } \\
\text { YongpingZhao (2011) }\end{array}$ & $\begin{array}{c}\text { Effect of CBI On English Majors'critical } \\
\text { Thinking Skills }\end{array}$ & Empirical \\
\hline 4 & $\begin{array}{l}\text { ShouhongWang } \\
\text { JinlingLiu } \\
\text { WenpingFu (2015) }\end{array}$ & $\begin{array}{l}\text { A Study on the Content-based College ESP } \\
\text { Instruction under the Background of MOOC } \\
\text { Era }\end{array}$ & Empirical \\
\hline 5 & JigangCai(2011) & $\begin{array}{c}\text { College English Textbooks to Cope with a } \\
\text { Transition: Principles and Problems }\end{array}$ & Empirical \\
\hline 6 & $\begin{array}{l}\text { JunyueChang } \\
\text { YongqingZhao (2010) }\end{array}$ & $\begin{array}{c}\text { Effect of CLI Curriculum for English Majors } \\
\text { at the Fundamental Stage }\end{array}$ & Empirical \\
\hline 7 & PeishengCao (2012) & $\begin{array}{c}\text { An Experimental Study on the Effectiveness of } \\
\text { CBI Theme-based Teaching Mode in College } \\
\text { English Teaching }\end{array}$ & Empirical \\
\hline 8 & $\begin{array}{c}\text { GuangxiaoShi } \\
\text { DejieZhao (2011) }\end{array}$ & $\begin{array}{c}\text { Content-based College English } \\
\text { Instruction:Liberal Education or ESP } \\
\text { Education }\end{array}$ & Conceptual \\
\hline 9 & PinghuaYuan (2010) & $\begin{array}{l}\text { An empirical study on the impact of CBI on } \\
\text { the critical thinking skill development of EFL } \\
\text { learners in the college English context }\end{array}$ & Empirical \\
\hline 10 & YihuaGu(2011) & $\begin{array}{c}\text { Discussion on ESP Teaching Models In } \\
\text { Technical Colleges Based on CBI Teaching } \\
\text { Concept }\end{array}$ & Conceptual \\
\hline 11 & $\operatorname{LiLi}(2010)$ & $\begin{array}{c}\text { A Study on Effects of Applying CBI to } \\
\text { Business English Teaching }\end{array}$ & Empirical \\
\hline 12 & $\begin{array}{l}\text { PinghuaYuan } \\
\text { TingLiu } \\
\text { LijuanWang(2010) }\end{array}$ & $\begin{array}{c}\text { The Impact of CBI on EFL Learners' Use of } \\
\text { English Learning Strategies and Their English } \\
\text { Proficiency }\end{array}$ & Empirical \\
\hline 13 & $\begin{array}{l}\text { JunyueChang } \\
\text { YangXia (2011) }\end{array}$ & $\begin{array}{c}\text { A Study of the Effects of the Content-Based } \\
\text { Instruction for English Majors in the Chinese } \\
\text { Context }\end{array}$ & Empirical \\
\hline 14 & $\begin{array}{l}\text { DongchunChen } \\
\text { (2014) }\end{array}$ & $\begin{array}{l}\text { College English Teaching and Teachers' } \\
\text { Professional Development under the Influence } \\
\text { of CBI Theory }\end{array}$ & Conceptual \\
\hline
\end{tabular}

\section{Analysis of Keywords using the CNKI}

After all relevant keywords were extracted from the articles; they were entered into the CNKI. As an example, the keywords CBI appear bigger than other words, indicating that they have been mentioned most frequently (Table 3). We can see that the research of content-based instruction is still at the theoretical level from these 
keywords, such as, college English, teaching model of CBI, Business English, college English teaching and so on. It means that content-based instruction development is becoming mature.

Table 3.Most frequent words used in the title of Content-based instruction studies in China

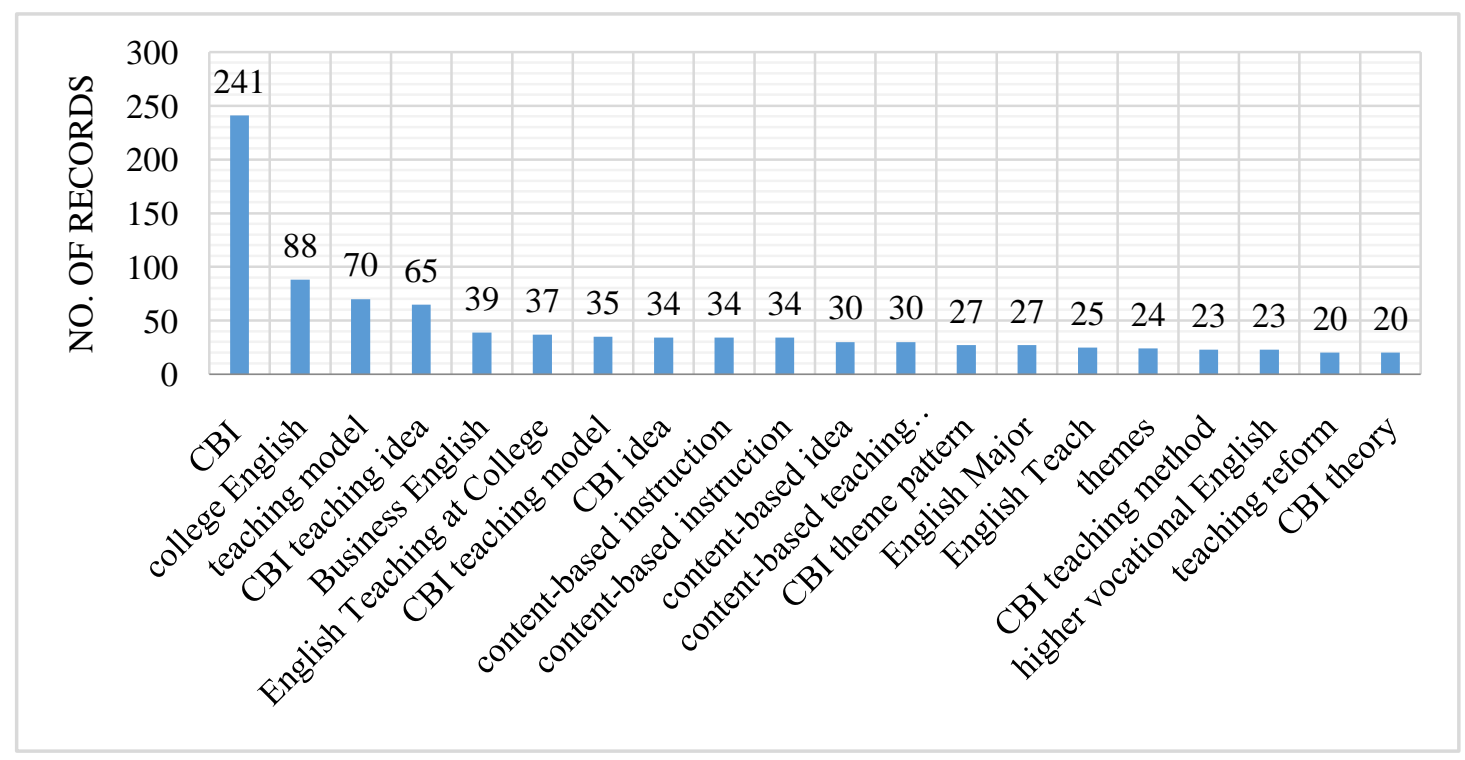

\section{Discussion}

Our analysis provides a general overview of the existing scientific research in China on the field of content-based instruction between 2010 and 2018 in terms of publications retrieved from the Web of National Knowledge Infrastructure (CNKI) database. The purpose of this research was to perform a bibliometric analysis using scientometric techniques, of nine years of research output in the field of content-based instruction so that it serves as a guide for future researchers who intend to develop studies on content-based instruction and need to acknowledge which academic journals, authors and articles should be addressed to attain a proper theoretical frame-work within this particular field of study.

Therefore it is necessary to create a comprehensive view of the status of research in this area, and a clear picture of the production process and scientific exchanges in the field. This will also aid in English teaching and educational policy-making. Undoubtedly, the schools play an important role in scientific production and acceleration of progress in every country.

Besides, we observe a noteworthy evolution of the published articles in this field of research. Initially, the articles in China focused on explaining theoretical models aimed at enabling the enhancement of the literature on this topic. There are three reasons. Firstly, content-based instruction (CBI) should vary from person to person. Secondly, there are a lot of difficulties in compiling CBI textbooks in China. Thirdly, basic English education is deeply rooted. For these reasons, it can be observed that this topic still should arise high doses of presence and interest among researchers. The results show that despite the literature is quite fragmented and shows a lack of consensus in certain issues, research developments are continually proliferating and expanding the number of approaches and understanding of content-based instruction.

\section{Conclusions and Future Work}

In this article we presented a bibliometric analysis of articles published in China by researchers between 2010 and 2018, analysing keywords indexed in National Knowledge Infrastructure and mapping the journals publishing the research. It shows content-based instruction in China is becoming mature. 
The conclusion that there is a great room for improvement with regard to the investigation of content-based instruction in China, namely by involving researchers and studies in terms of content-based instruction, is useful for researchers that might be interested in the subject as well as to research managers and policy makers at the central government and at the universities and other research centers.

The study presented in this article should include articles that do not constrain their scope to the CNKI, relying hence on the use of other online databases, as for example Scopus or Google Scholar. These databases might contain studies published in journals that are not indexed within the National Knowledge Infrastructure. This could allow detecting if the low visibility of content-based instruction research in China is only due to the limited number of researchers and institutions involved in the subject research.

\section{References}

[1] Shih M (1986). Content-Based Approaches to Teaching Academic Writing.Tesol Quarterly. (4):617-648.

[2] JigangCai (2010).Reflections on The Reorientation of College English Teaching in China.Foreign Language Teaching And Research. (4):306-308.

[3] PinghuaYuan (2006). Motivation And Teaching Meta Model of Foreign Language Teaching Based on Curriculum Content.Degree And Graduate Education. (3):31-36.

[4] Lambert W E, Tucker G R (1972). Bilingual Education of Children: The St. Lambert Experiment. Tesol Quarterly. 7(3):248.

[5] StephenD (1985). The Input Hypothesis :Issues And Implications. Longman.

[6] Brinton D, Snow M A, Wesche M B (2010). Content-based Second Language Instruction. Elt Journal. 50(9):432.

[7] Grabe W,StollerFL (1997). Content-based Instruction: Research Foundations. In Snow.

[8] Leaver BL, Stryker SB (1989). Content-based Instruction For Foreign Language Classrooms. Foreign Language Annals. (3):269--275.

[9] Runqingliu (2011). Content Driven Language Teaching. The lecture paper at the second annual conference of Chinese educational linguistics.

[10] Shanghai College English Teaching Steering Committee the reference frame of College English Teaching in Shanghai (Trial) (2013).Beijing Higher Education Press.

[11] JigangCai (2012). Where is The Way of College English Teaching in China?.Shanghai Jiao Tong University press.

[12] Zhenbang Zhang (2003). On The Chapter Bryan Problems in Teaching Reform of China's Foreign Language.Foreign Language. (4):1-6.

[13] PeishengCao (2012). Experimental Study on The Effectiveness of College English CBI Theme Teaching Model. Foreign Language Teaching.(3):51-55.

[14] YihuaGu (2011). ESP Teaching Mode in Higher Vocational Colleges Based on CBI Teaching Concept. Foreign Language. 27 (5):134-137.

[15] DongchunChen (2014).College English Teaching And Teacher Professional Development Under The CBI Concept. Foreign Language Teaching. (2):68-73.

[16] Qiufang Wen (2014). For General English And Special English in College English Teaching: Problems And Countermeasures of. Language Teaching. (1):1-8.

[17] Youzhong Sun, LiwenLi (2011).CBI And ESP And The Direction of English Major And College English Teaching Reform in Chinese Universities. Foreign Language Research. (5):1-4.

[18] Liming Yu, JianxiaHan (2012).Content or language -- Reflections on College English Teaching in China. Foreign Language and Foreign Language Teaching.(3):1-4.

[19] Junhan Mao, TingtingLiu (2013). Review of CBI Teaching Research in China for Ten Years. Contemporary 
Educational Theory and Practice. 5 (12):117-119.

[20] FeirongGu, GuizhenShi (2009). An Empirical Study of CBI Teaching in College Oral English. Foreign Language and Foreign Language Teaching. (11):32-34.

[21] QingningDai(2006).CBI Concept And Bilingual Teaching. Chinese Adult Education. (2):108-109.

[22] Jing Xu (2012). The Research of CBI Inland And Abroad. Teaching Method Research. (7):295-296.

[23] Lianying Liu,Gang Lu (2014). Overview of CBI Research in Recent 20 Years in China. Journal of Hubei University of Economics. (11):177-178.

[24] JingpingDu, ShaoliDeng (2012). On The Relationship Of ESP, ELE, CBI, Bilingual Teaching And College English.Crazy English Teacher Edition. (3):40-42+46+207.

[25] Pinghua Yuan, Liming Yu (2008). An empirical Study on Content-based Instruction in The Chinese College English Context. Foreign Language Teaching and Research. 40 (1):59-64.

[26] FeirongGu, GuizhenShi (2009). An Empirical Study on Applying CBI to College Spoken English Teaching.Foreign Language and Foreign Language Teaching. (11):32-34. 